\title{
Features of pollution of plowlands by heavy metals from motorways
}

\author{
O. Ivashchenko, \\ Academician of the NAAS, Doctor of Agricultural Sciences Institute of Bioenergetic Cultures \\ and Sugar Beet NAAS \\ V. Shvartau, \\ Corresponding Member of NAS of Ukraine, Doctor of Biological Sciences \\ Institute of Plant Physiology and Nanosciences of Ukraine \\ O. Ivaschenko, \\ doctor of agricultural sciences \\ V. Andreyev \\ Institute of Plant Protection of NAAS
}

The purpose. To determine features of contamination of plowlands with pollutants - lead, manganese and cadmium from motorways. Methods. Analysis of content of heavy metals is made using method of ICP-MS on emissive mass analyzer Agilent 7700x. Results. With increase of distance from polluter (motorway Kiev-Odessa) the density of products of incineration of car fuel in ground layer of air and their accumulation in arable layer of soil drops. Conclusions. The highest levels of accumulation of heavy metals in soil have been fixed within the distance of $5 \mathrm{~m}$ of the road. At the distances over $1280 \mathrm{~m}$ from the motorway the level of accumulation of lead drops in 1,67 times, manganese $-1,07$, cadmium in 40 times.

Key words: heavy metals, mass-spectrometry, contamination of soils.

Human activity essentially accelerates the movement of natural substances and different pollutants entering the soil's arable layer [1 - 4]. In addition to industrial pollution - by-products of activity of energy, metallurgical, mining, concentrating, chemical and communal objects, the pollution also enters the soil, which are transferred from highways as a result of road transport [5].

Among the products of combustion of automotive fuel, nitrogen, carbon, lead, manganese, cadmium and other chemical elements are added to the ground layer of air and then from aerosols in the arable layer of soil [6-8]. A part of such compounds can bind to inorganic and organic substances of the soil complex present in the arable layer $[9,10]$.

The transition of compounds of heavy metals to the soluble state and colloids contribute to low $\mathrm{pH}$ of the medium. Accordingly, such compounds acquire the ability to translocate and adhere to plant tissues [11]. The danger of pollution of heavy metals by surface water (water of rivers and lakes, groundwater up to $50 \mathrm{~m}$ deep) is also increasing [12]. The ability to move compounds of heavy metals in water is influenced by the availability of free oxygen and the concentration of carbon dioxide [13].

Compounds of heavy metals pollute the arable layer of soil, but it is possible and its release from such an undesirable presence [14]. The half-life from the soil of heavy metals as a result of the natural migration of chemical elements and their compounds is quite long. For example, for lead - $770-5900$ years, cadmium - $13-110$ years, zinc - 70-510 years, copper - 310 - 1500 years [15].

Under the anaerobic conditions of the medium, a large number of heavy metal compounds become more accessible to plants; therefore, the excess of the presence of water in the arable layer of soils contributes to the processes of transition of heavy metals in soluble forms [16].

The purpose of the research is to establish the main patterns of contamination of arable land near highways with heavy metals - lead, manganese, cadmium. 
Methods. The research was conducted in 2016-2017 on arable lands in the Vasylkivskyi district of the Kyiv region, which directly adjoins the Kyiv-Odessa highway. The soil of the fields where the soil samples were taken for analysis, the dark gray podzol, typical soil for the northern part of the forest-steppe of Ukraine.

The $25 \mathrm{~m}^{2}$ plots in a 6-fold repetition were placed at a distance from the road of the road: $5,10,20,40$, $80,160,320,640$, and $1280 \mathrm{~m}$. Samples of soil were taken from the arable a layer $(0-30 \mathrm{~cm})$ at 5 points on plots of each repetition, and after a thorough mixing, a mean sample of $2 \mathrm{~kg}$ was taken. The analysis of the content in the soil of heavy metals was conducted at the Institute of Plant Physiology and Genetics of the National Academy of Sciences of Ukraine. Determination of the elemental composition in the experimental samples was carried out by the method of ICP-MS on the emission mass-spectrometer Agilent 7700x. The samples were dried to constant weight and digested in ICP-grade nitric acid with Milestone Start D microwave digestion system. The extract was adjusted to $50 \mathrm{ml}$ with water of the 1-st class (18 Mom) prepared on a Scholar-UV Nex Up 1000 (Human Corporation, Korea).

The results of the experiments were processed statistically according to the standard methods [3,4], using the Exel program and with the mathematical processing of the data obtained using the professional program Statistica 8.0. Dispersion analysis was used, differences between the mean values were considered probable at $\mathrm{P}<0.05$.

Results. The road, especially with heavy traffic, is a powerful source of environmental pollution. Automobile transport, as a result of the work of internal combustion engines, throws into the surface layer of air different combustion products. Air streams combustion products from the road can be spread on adjacent areas and gradually settling on vegetation and soil surface. In products of combustion of fuel and technological additives that are present in it, in the surface layer of the atmosphere there are numerous pollutants, including compounds of heavy metals accumulated in the arable layer.

Contamination that creates cars is less noticeable compared to pollution of industrial facilities, but in the case of a large number of vehicles, the negative impact of exhaust gases can significantly outweigh the anthropic side effects, for example - from the plant. The chemical composition of exhaust gases of cars is diverse and is harmful to living organisms. In the air for a long period of time the gaseous and solid particles in the form of aerosols freeze the fuel combustion products with internal combustion engines.

Widespread use of anti-knock additives for fuels, primarily tetraethyl lead (TEL) and compounds of manganese as a result of combustion, leads to their entry into the atmosphere and dispersion in large areas. TEL has a high level of toxicity and is well accumulating in the human body. It is accumulated in bone tissues, in liver and kidney cells. Even under intense treatment, the removal of lead compounds from the human body occurs very slowly. The MAC (maximum acceptable concentration) for TPPs in water, air and food is not allowed for humans.

Due to the gasified exhaust gases and the polluted air as a result of breathing, inhabitants and workers involved in the performance of their duties at a short distance from motorways receive up to 90 $\mu \mathrm{g}$ per day of lead compounds, including in the form of TEL (tetraethyl lead - $\left(\mathrm{C}_{2} \mathrm{H}_{5}\right)_{4} \mathrm{~Pb}$ ) through the lungs. Lead and its compounds come into the human body and with water and food from food plants that have been grown in areas adjacent to highways with intensive traffic. Such an inflow can reach 250-300 $\mu \mathrm{g} /$ day.

Lead compounds, especially TEL, are readily soluble in organic solvents, fats and lipids, where they can accumulate. TEL is a carcinogen, it is very poisonous and belongs to the 1st class of hazardous substances.

The lead compounds from airborne aerosol gradually settle down and enter the arable layer of soil in the fields adjacent to the motorway.

As a result of the studies, it was proved that the content of lead compounds in soil samples varied from distance to road.

The highest concentration of lead compounds $-11.40 \mathrm{mg} / \mathrm{kg}$ was recorded near the roadway.

In samples of soil, which were taken at a distance twice as big as the previous version $(10 \mathrm{~m})$, the concentration of lead compounds was lower, it reached $7.86 \mathrm{mg} / \mathrm{kg}$ or $68.9 \%$ of the previous one. Thus, 
most of the dust particles of the combustion products of automotive fuel, containing lead compounds, settle directly on the roadway.

Smaller-sized solid particles and gaseous substances that enter the airflow as a result of the internal combustion engines exhibit high levels of mobility. Convection air flows can move them over long distances.

The analyzes of the following soil samples from the arable layer, which were taken at a distance from the road, were consistently detected at $40,80,160,320$, and $640 \mathrm{~m}$ of lead compounds $(\mathrm{Pb})$ within the range of $7.72-7.22 \mathrm{mg} / \mathrm{kg}$. That is, at such distances from the source of contamination of the deposition of lead compounds, primarily in the form of small dust particles from air currents, occurs relatively evenly (table).

Only at a distance of $1280 \mathrm{~m}$ from the canvas of the freeway, the magnitude of the accumulation of lead compounds in soil samples on arable land showed a tendency to a statistically significant decrease and amounted to $6.85 \mathrm{mg} / \mathrm{kg}$, or $60 \%$ of the maximum values in the experiments.

Table. Level of contamination of arable land with heavy metals ( $\mathrm{mg} / \mathrm{kg}$ of soil) near the KyivOdessa highway in 2016-2017, $\mathrm{n}=30$

\begin{tabular}{|l|c|c|c|c|c|c|c|c|c|}
\hline \multirow{2}{*}{$\begin{array}{l}\text { Heavy } \\
\text { metals }\end{array}$} & \multicolumn{8}{|c|}{ Distance of sampling of soil from road, $\mathrm{m}$} \\
\cline { 2 - 10 } & 5 & 10 & 20 & 40 & 80 & 160 & 320 & 640 & 1280 \\
\hline $\mathrm{Pb}$ & 11,40 & $7,86^{*}$ & 8,21 & 7,72 & $7,36^{*}$ & 7,37 & 7,54 & 7,22 & $6,85^{*}$ \\
\hline $\mathrm{Mn}$ & 283,5 & 283,7 & $289,9^{*}$ & $292,7^{*}$ & $277,7^{*}$ & 278,7 & 276,0 & 273,4 & $264,3^{*}$ \\
\hline $\mathrm{Cd}$ & 0,320 & $0,092^{*}$ & $0,061^{*}$ & 0,088 & 0,072 & 0,079 & $0,019^{*}$ & 0,016 & 0,017 \\
\hline
\end{tabular}

Note: ${ }^{*}$ - the differences between the variantes, from 5 to $1280 \mathrm{~m}$, are statistically significant as $\mathrm{P}<$ 0.05 .

Note that on acid soils ( $\mathrm{pH}$ values of soil solution less than 5,5 ), lead compounds can pass into the soluble state in the form of real solutions or colloids, interact with the soil absorbing complex and enter plants and enter into biological cycle cycles. The TEL is a particularly dangerous compound. It is these lead compounds that are primarily a source of contamination of arable land adjacent to highways.

Compared to the amount of lead, the content of manganese and its compounds in the soil was significantly higher. The manganese is quite common in the earth's crust. It is present predominantly in the form of sulfide compounds of sedimentary rocks. As a result of interaction with water and air, such substances are capable of migration, often at considerable distances.

Manganese and its compounds are fed into exhaust gases of automobiles, mainly from two sources: anti-detonating additives and cylinder walls of engines made of alloyed steel and containing manganese $(\mathrm{Mn})$ in their composition.

In the form of solid powders of aerosols, manganese compounds, as a result of combustion of motor fuel, enter the surface layers of the atmosphere and dissipate in the wind to large areas. Gradual sedimentation of such particles leads to their accumulation in an arable layer of soil.

Significant proliferation of manganese compounds in the environment reduces the contrast of the magnitude of its revenues from roads on adjacent arable land. At a distance of $5 \mathrm{~m}$ from the road, the content of manganese compounds in the arable layer was $283.5 \mathrm{mg} / \mathrm{kg}$ of soil, and an increase in the distance from the road had little effect on the reduction of the presence of manganese compounds in the arable layer. At the maximum distance of $1280 \mathrm{~m}$, the presence of manganese compounds in the arable soil layer was $264.3 \mathrm{mg} / \mathrm{kg}$, or $93.2 \%$ of the value recorded at a distance of $5 \mathrm{~m}$ from the road.

Manganese in an arable layer of soil is, predominantly, in an insoluble state, therefore its entree to plants is limited.

The most dangerous for man is the presence of manganese compounds in the air. The presence of compounds of manganese in air of populated areas above $0.01 \mathrm{mg} / \mathrm{m}^{3}$ is harmful to humans. As a result of breathing of such air there is a gradual, progressive destruction of the nervous system. 
Manganese compounds are in the second grade of danger. Compared with the problems of contamination of territories, including arable land with lead compounds, the presence of compounds of manganese is less dangerous.

Anti-detonating manganese-based fuel additives are more environmentally friendly than TEL, however, and they are not completely neutral to the environment.

The dangerous pollutant of arable land is a cadmium ( $\mathrm{Cd}$ ) and its compounds. The main source of cadmium in biological systems is as a result of anthropogenic activity. Almost $52 \%$ of environmental pollutions with cadmium and its compounds is due to combustion processes of fuel containing compounds of this heavy metal in its composition. Cadmium compounds are present in petroleum products. Present compounds of cadmium and in mineral fertilizers that are widely used in modern intensive agriculture.

As a result of the combustion processes, cadmium and its compounds enter the surface layers of the atmosphere and settle on the surface of the soil and are included in the soil absorption complex of arable land.

The analysis of soil samples taken on arable land at different distances from the road revealed significant changes in the level of accumulation of cadmium compounds in the arable layer. The largest accumulation levels of cadmium compounds were recorded in samples taken at a distance of $5 \mathrm{~m}$ from the highway. The presence of cadmium compounds reached $0.320 \mathrm{mg} / \mathrm{kg}$ of soil. Increasing the distance of sampling points from the road to $10 \mathrm{~m}$ showed a significant decrease in the amount of arable layer contamination by cadmium compounds. The accumulation of cadmium was already $0.092 \mathrm{mg} / \mathrm{kg}$ of soil, or $28.8 \%$ of the previous levels.

At a distance of $160 \mathrm{~m}$ from the road detected of $0.079 \mathrm{mg} / \mathrm{kg}$ of ground of cadmium compounds. The dynamics of the changes in the accumulation values in the arable layer of cadmium and its compounds indicates that with the increase in the distance from the source of pollution and the decrease of concentration indicators in the surface layer of pollutants, the intensity of their precipitation and accumulation decreases. At a distance of $160 \mathrm{~m}$, the accumulation of this heavy metal was $24.7 \%$ of the $5 \mathrm{~m}$ level.

Conducting analyzes of samples taken at the maximum in distance studies from the road revealed that they had cadmium compounds in the amount of $0.008 \mathrm{mg} / \mathrm{kg}$, or $2.5 \%$ of the maximum in experiments.

Cadmium compounds in the arable layer, which are in an insoluble state, and for most organisms, including plants, are little available. However, due to low $\mathrm{pH}$ values (5.5 and less) as a result of root extracts, the interaction with the soil moisture of the cadmium compound passes into the soluble state and in soil colloids and can be absorbed by plants.

Together with foods, cadmium compounds can get into the human body. Cadmium blocks the activity of numerous enzymes and, accordingly, the course of biochemical reactions that provide vital activity of the organism. By the level of toxic effects on the human body, cadmium compounds belong to the first class of danger.

The established MAC in foods for cadmium and its compounds does not exist. His presence in food is unacceptable. The dangerous presence of cadmium and its compounds in the air of settlements and industrial zones also. Inhalation of air with the presence of aerosol in particles of cadmium compounds at a concentration of $5 \mathrm{mg} / \mathrm{m}^{3}$ during 8 hours is lethal to humans.

Therefore, the presence of cadmium and its compounds in the environment, including in the arable layer of arable land, is a very topical issue and requires a comprehensive solution as a way of improving the technological processes in which cadmium and its compounds enter the atmosphere, water and soil.

At the same time, the problem of improving the protection and purification of arable land from pollution of cadmium and its compounds from the arable layer of soil, first of all, on arable lands adjacent to highways deserves attention. This way will eliminate the risk of cadmium and its compounds contamination of foods. 


\section{Conclusions}

Among the great variety of heavy metals coming from highways in arable land, one of the most dangerous are lead $(\mathrm{Pb})$, manganese $(\mathrm{Mn})$, cadmium $(\mathrm{Cd})$ and their compounds, which are included in biological cycles and come from the soil into the agricultural plants.

The increase in the distance from the source of pollution (on the example of the Kyiv-Odessa highway) reduces the concentration of automotive fuel combustion products in the surface layer of air and, accordingly, its accumulation in the arable soil layer. The largest levels of accumulation of heavy metals in the arable layer were installed at a distance of $5 \mathrm{~m}$ from the road, and the smallest - at a distance of $1280 \mathrm{~m}$. As a result of an increase in the distance of the decrease equal to the accumulation was: lead in 1,67 times; manganese -1.07 times, cadmium - 40 times.

To protect and clean arable land from contamination by lead compounds, manganese and cadmium, it is necessary to develop a set of measures that should reduce the level of anthropogenic pollution and neutralize and remove such pollutants from the arable soil layer.

\section{Bibliography}

1. Рейтерс Н.Ф. Экология (теория, законы, правила, принципы и гипотезы). - М.: Россия молодая, 1994. - 325 с.

2. Дмитрук Ю. М. Еколого-геохімічний аналіз ґрунтового покриву агроекосистем - Чернівці: Рута, 2006. - 328 c.

3. Бреславець A.І. Техногенно забруднені ґрунти та шляхи їх поліпшення. Проблеми охорони навколишнього природного середовища та екологічної безпеки: зб. наук. пр. / під ред. Г.Д. Коваленко. Харків: Райдер, 2009; 31: 189-202.

4. Velma V., Tchounwou P. B. Hexavalent chromium-induced multiple biomarker responses in liver and kidney of goldfish, Carassius auratus // Environ. Toxicol., 2011, vol. 26, no 6, pp. 649-656.

5. Трахтенберг И.М., Колесников В.С., Луковенко В.П. Тяжелые металлы во внешней среде: Современные гигиенические и токсикологические аспекты. - Минск: Навука і тэхніка, 1994. - 285 с.

6. Distribution of Chromium Contamination and microbial activity in soil aggregates / T.K. Tokunaga, J. Wan, T.C. Hazen [et al.] // J. Environ. Qual. - 2003. - Vol. 32. - P. 541-549.

7. Prasad, M.N.V., Freitas, H.M.O. (2013): Metal hyperaccumulation in plants-Biodiversity prospecting for phytoremediation technology. Electronic Journal of Biotechnology 6 (3):285-321.

8. Смирнов М.И. Сравнительная гигиеническая оценка токсичности и опасности ионов хрома в воде с учетом влияния на развитие экспериментального атеросклероза: Автор. дис. ... канд. мед. наук. - М., 1984. -20 с.

9. Алексеенко А.А. Экологическая геохимия. - М., 2000. -627 с.

10. Водяницкий Ю.Н. Об опасных тяжелых металлах/металлоидах в почвах // Бюлл. Почвенного ин-та им. В.В. Докучаева. - 2011. - Вып. 68. - С. 56-81.

11. Thurman D. A. Mechanism of metal tolerance in higher plants // Effect of heavy metal pollutions on plants: in 2 vol. Ed. Lepp N. W. - L. N. Jersey: Applied Science Publ. 1981. V. 2. P. 239-249.

12. Morais S., Costa F.G., Pereira M.L. Heavy Metals and Human Health. Environmental Health Emerging Issues and Practice / Ed. by J.Oosthuizen. InTech, 2012: 227-246.

13. Збірник міжнародно-правових актів у сфері охорони довкілля. - 2-е вид., допов. - Львів: Норма, 2002. - 416 c.

14. Лікарські засоби / Належна практика культивування та збирання вихідної сировини рослинного походження, СТ-Н МОЗУ 42-4.5:2012, Видання офріційне, -К.: МОЗ України, 2012. - 13 с.

15. Меньщикова Е.Б., Ланкин В.З., Зенков Н.К., Бондарь И.А., Круговых Н.Ф., Труфакин В.А. Окислительный стресс. Прооксиданты и антиоксиданты. - М., 2006. - 556 с.

16. Bopp L., Ehrlich H. Ensimatic reduction of $\mathrm{Cr}^{6+}$ by a strain of Pseudomonas fluorescens // Abstr. annu. meet. amer. soc. microbial. - Washington, D.C., 2000. - P. 212-216. 